\title{
Lack of Association between Using Aspirin and Development of Non-Hodgkins Lymphoma: A Meta-analysis
}

\author{
Maria Cheraghi $^{1 *}$, Neda Amoori ${ }^{2 *}$, Hosein Fallahzadeh $^{3}$, Hossein Rahmani ${ }^{4}$
}

\begin{abstract}
Background: Non-Hodgkins lymphoma (NHL) is a heterogeneous group of malignancies, originating in the lymphatic organs, whose incidence is increasing in developed as well as developing countries. Epidemiological evidence suggests that aspirin may reduce the incidence and mortality of several cancers. The main objective of this study was to evaluate the potential relationship between using aspirin and development of NHL with a meta-analysis. Materials and Methods: A total of 7 studies were included. Outcome was calculated and reported as odds ratios (ORs). Heterogeneity was assessed with Cochrane $Q$ and $I^{2}$ statistics. Dissemination bias was evaluated by funnel plot visualization and trim-and-fill analysis. Results: Our analysis showed OR of developing NHL overall of $1(95 \%$ CI: $0.87-1.16$, $p=0.9)$, and in females this was $0.81(95 \% \mathrm{CI}$ : $0.72-.92, p=0.001)$ and in males 1.01 (95\% CI: 0.82-1.26, $\mathrm{p}=\mathbf{0 . 8 6}$ ). The odds ratio (OR) of chronic lymphocytic leukemia/small lymphocytic lymphoma (CLL/SLL) was 0.85 (95\% CI: 0.75-0.97, p=0.02), The ORs of follicular lymphoma (FL) and large B-cell lymphoma (DLBCL) in individuals exposed to aspirin were $1.12(95 \% \mathrm{CI}: 0.86-1.45, \mathrm{p}=0.37)$ and 1.03 (95\% CI: 0.9-1.19, $\mathrm{p}=\mathbf{0 . 6})$ respectively. Conclusions: In conclusion, individuals taking aspirin do not demonstrate any change in risk of Non-Hodgkins lymphoma.
\end{abstract}

Keywords: Non-Hodgkins lymphoma - aspirin - meta-analysis - negative influence

Asian Pac J Cancer Prev, 16 (2), 787-792

\section{Introduction}

Non-Hodgkins lymphoma (NHL) is a heterogeneous group of malignancies that originates in the lymphatic organs (Zelenetz et al., 2010; Sangrajrang et al., 2011; Amanat et al., 2013). NHL is the seventh most common cancer and the sixth leading cause of death from cancer in USA (Hernandez et al., 2010; Amoori et al.,2014). Mortality rate of this type of cancer has substantially increased (Clarke et al., 2002; Zekri et al., 2013) in developed countries as well as developing countries and will double every 20 years (Devesa et al., 1992; Broccia et al., 2001) It more occurs because of malfunction of immune system, including primary immunodeficiency syndromes, immunosuppressive drugs for transplant patients, and the immunodeficiency human virus (HIV) (Ansell et al., 2005; Yildirim et al., 2013). Other effective factors are rheumatoid arthritis, diabetes mellitus, overweight (Baecklund et al., 2006; Setoguchi et al., 2006; Hoshida et al., 2007) a history of allergy, family history of cancer (Baecklund et al., 2006; Goldin et al., 2009), taking drugs, such as phenytoin and chemotherapy (Chang et al., 2005; Karami et al.,2014), and exposure to pesticides, especially phenoxy herbicides (Boffetta et al., 2007; Chia et al., 2012) has been increased risk of NHL. The evidence suggests that aspirin may reduce the incidence and mortality of several cancers (Rothwell et al., 2011; Rothwell et al., 2012). And it has been shown to have a protective effect for colorectal cancer (Thun et al., 2012; Amoori et al.,2014). However, there was not a stable relation between taking drugs as Non-steroidal Anti Inflammatory (NSAISs), including aspirin, and NHL. Therefore, we performed a meta-analysis study to evaluate the potential relationship between using aspirin and the development of NHL.

\section{Materials and Methods \\ Literature and search strategy}

We searched PubMed, Cochrane Library, Medline, and Science Citation Index Expanded databases for casecontrol and cohort studies on taking Aspirin, and NHL in English. The following search terms were used: (Nonhodgkins lymphoma, NHL, Aspirin, Folicular lymphoma, FL, Diffuse large Bcell, DLBCL, Cronic lymphocytic leukemia, CLL/SLL, cohort, case control, observational 


\section{Maria Cheraghi et al}

studies, non-steroidal, corticosteroids, and NSAIDs. In addition, reference lists were also reviewed manually. The latest research was performed on October 2014.

Inclusion and exclusion criteria

In order for articles to be included in our study, the following criteria must be met: 1) case-control or cohort studies; 2) evaluating the relationship between taking Aspirin and the NHL;3) providing raw data, or relevant information which could be used to calculate an odds ratios (ORs) with $95 \%$ confidence intervals (CI). The exclusion criteria included: 1) repeated reports; 2) case reports, editorials, review articles, conference papers and meta-analysis.

\section{Data extraction and synthesis}

All publications retrieved from the databases were examined by two independent reviewers (Maria Cheraghi and Neda Amoori) and disagreements were solved by researcher Hosein Fallahzadeh. For each eligible study, the following characteristics were collected: first author, year of publication, Area, study design, Source of case, sources of control, Ascertainment measure, Adjustment factor.

\section{Statistics and analysis}

Meta-analysis using Comprehensive Meta Analysis (v.2.0; Biostat, Englewood, NJ, USA) software was conducted All results were reported at the pooled ORs and 95\% CI . To measure the effect of exposure on the outcome studied, measurements "Relative Risk (RR)", "Attributable Risk (AR)", and Hazard Ratio (HR)" in cohorts studies, and "Odds Ratio (OR)" in case-control studies were applied.To evaluate qualitatively heterogeneous data, the chi-square test was used in confidence level of $10 \%$ $(\mathrm{p}<0.1)$. The test "I2" (Higgins et al., 2003) was used to assess quantitative heterogeneity in the results so that if $\mathrm{I}^{2}$ is greater than $50 \%$, heterogeneity will be severe. To estimate the variances between studies, the statistical method "tau-squared" was applied. Statistical models like fixed effect or Mantel Haenszel, and random effect (REM) or Dersimonian-laird were used for the analysis and integration of results. REM was calculated to determine heterogeneity of studies. Publication bias was assessed by Begg's funnel plot . Forest plots were drawn to compare the extracted parameters from the studies.

\section{Results}

\section{Literature search}

A total of 7 published articles regarding the relationship between taking Aspirin, and NHL the NHL were identified by applying the inclusion criteria (Figure 1) (kato et al., 2002; Erber et al., 2009; Teras et al., 2013; Flick et al., 2006; Cerhan et al., 2003; Zhang et al., 2006; Baker et al., 2005) and 3 articles reported intake red meat and risk subtype NHL(Erber et al., 2009; Teras et al; Baker et al., 2005).

\section{Study characteristics}

The main characteristics of the 7 studies are as follows, of which 4 were population-based case-control studies

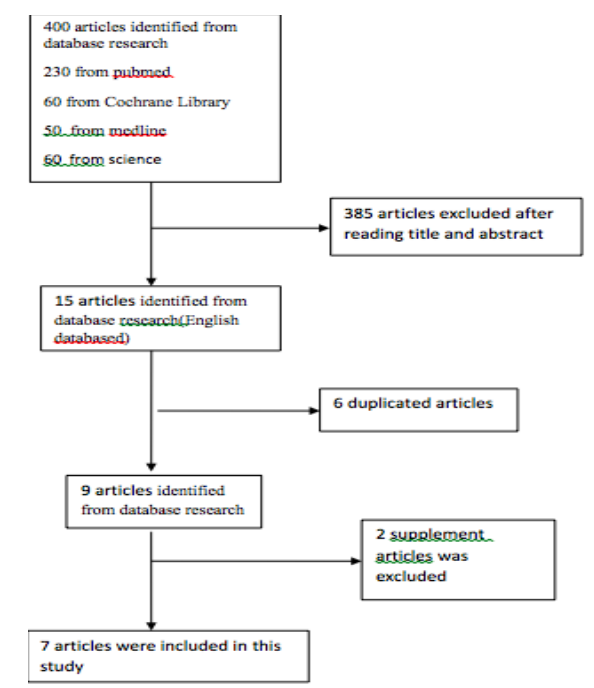

Figure 1. Flow Chart of Study Selection
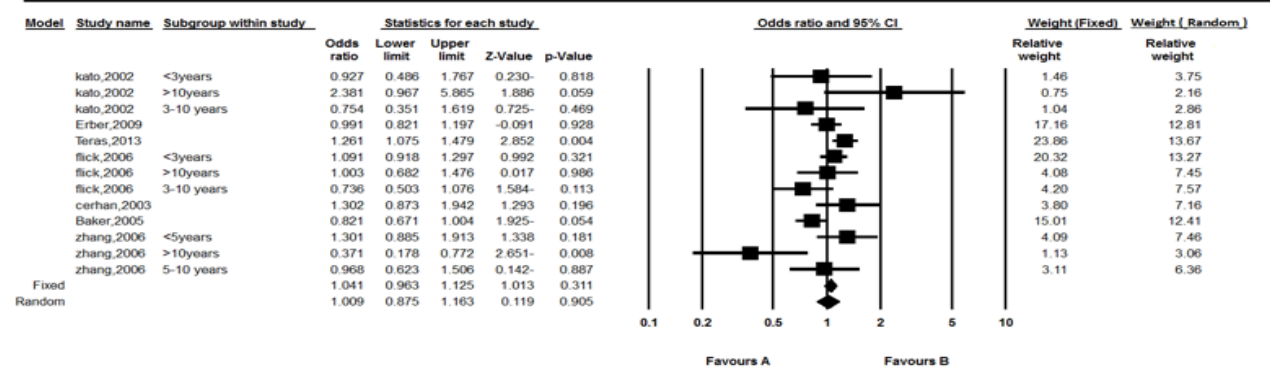

Figure 2. Forest Plot of Odds Ratio Estimates of NHL for Persons who Received Aspirin

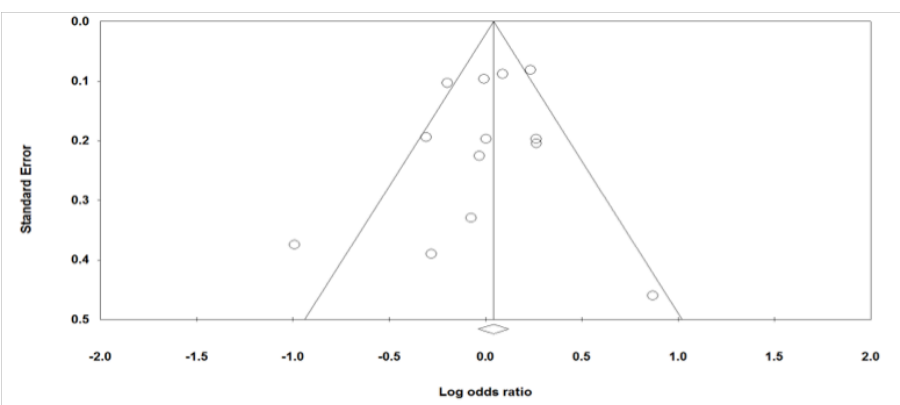

Figure 3. Funnel Plot of Studies of NHL Risk After Aspirin Exposure 
and 3 were cohort study. Eleven studies were published between 2002 and 2013 and involved 5308 cases and 9086 controls. More details of these studies are summarized in Table 1.

\section{Results of meta-analysis}

Using the random-effect model, meta-analysis was showed was not a significant association between the taking Aspirin and NHL risk $(\mathrm{OR}=1.0,95 \% \mathrm{CI}$ : 0.87 1.16, $\mathrm{p}=0.9$ ), the forest plot was shown in Figure 2. The
Aspirin Does Not Influence Risk of Non-Hodgkins Lymphoma publication bias among studies of intake and NHLrisk was not appreciable based on funnel plots (Figure 3).

Outcome of three studies has evaluated in female participants. The NHL risk in females was 0.81 (95\% CI top: $0.72-.92, \mathrm{p}=0.001$ ). Three studies evaluated outcomes in male participants. The NHL risk in males was 1.01 (95\%CI bottom: 0.82-1.26, p=0.86) (Figure 4).

Taking aspirin and sub group NHL risk

Analysis using the available data of taking Aspirin also

Table 1. Characteristics of the Studies Correlating with the Effects Exposure Aspirin on NHL Risks

\begin{tabular}{|c|c|c|c|c|c|c|}
\hline NO & Study(ref.) & Area & Source of case & Source of controls & $\begin{array}{l}\text { Ascertainment } \\
\text { measure }\end{array}$ & $\begin{array}{l}\text { Adjustment } \\
\text { factor }\end{array}$ \\
\hline 1 & Flick et.al,2006 & California & $\begin{array}{l}\text { Northen } \\
\text { California cancer } \\
\text { centers SEER, } 415\end{array}$ & $\begin{array}{l}\text { Population } \\
\text { controls sampled } \\
\text { by random digit } \\
\text { dialing and from } \\
\text { medical services } \\
\text { file,501 }\end{array}$ & $\begin{array}{l}\text { Face to face } \\
\text { interviews }\end{array}$ & $\begin{array}{l}\text { Age, sex, } \\
\text { residence }\end{array}$ \\
\hline 2 & Zhang et.al,2006 & USA & $\begin{array}{l}\text { Newly } \\
\text { hospitalized } \\
\text { patients, in } \\
\text { Newyork, } \\
\text { philadelphia, } \\
\text { Boston and } \\
\text { batimore,529 }\end{array}$ & $\begin{array}{l}\text { Population } \\
\text { controls selected } \\
\text { hospitalized } \\
\text { patients, in } \\
\text { Newyork, } \\
\text { philadelphia, } \\
\text { Boston and } \\
\text { batimore,2013 }\end{array}$ & Interview & $\begin{array}{l}\text { Age, sex, study } \\
\text { center, year of } \\
\text { interview }\end{array}$ \\
\hline 3 & Baker et.al,2005 & Newyork & $\begin{array}{l}\text { Buffalo country } \\
\text { cancer registry }\end{array}$ & $\begin{array}{l}\text { Population } \\
\text { controls sampled } \\
\text { by random digit } \\
\text { dialing and from } \\
\text { medical services } \\
\text { file, } 2512\end{array}$ & Questionnaire & Sex, age \\
\hline 4 & Kato et.al,2002 & Newyork & $\begin{array}{l}\text { Cancer registry } \\
\text { in the upstate } \\
\text { counties of new } \\
\text { York state(NYS) }\end{array}$ & $\begin{array}{l}\text { Control selected } \\
\text { from random } \\
\text { sample from the } \\
\text { NYS Department } \\
\text { of Motor vehicles } \\
\text { license file(DMV) }\end{array}$ & $\begin{array}{l}\text { Telephone } \\
\text { interviews }\end{array}$ & Age \\
\hline 5 & Cerhan et.al,2003 & United state & $\begin{array}{l}\text { Iowa death } \\
\text { certificate and } \\
\text { cancer registry } \\
\text { file }\end{array}$ & $\begin{array}{l}\text { Iowa women } \\
\text { health study }\end{array}$ & $\begin{array}{l}\text { Mailed } \\
\text { questionnaire }\end{array}$ & NR \\
\hline 6 & Erber et.al,2009 & $\begin{array}{l}\text { United state(Los } \\
\text { Angeles, Hawaii) }\end{array}$ & $\begin{array}{l}\text { Hawaii tumor } \\
\text { registry Los } \\
\text { Angeles } \\
\text { country cancer } \\
\text { surveillance } \\
\text { program, state of } \\
\text { California cancer } \\
\text { registry }\end{array}$ & $\begin{array}{l}\text { Multiethnic } \\
\text { cohort(MEC) } \\
\text { study }\end{array}$ & $\begin{array}{l}\text { Mailed } \\
\text { questionnaire }\end{array}$ & $\begin{array}{l}\text { Ethnicity, } \\
\text { education, body } \\
\text { mass index and } \\
\text { alcohol intake }\end{array}$ \\
\hline 7 & Teras et.al,2013 & United state & $\begin{array}{l}\text { Cancer self } \\
\text { report,medical } \\
\text { records and state } \\
\text { cancer registry }\end{array}$ & $\begin{array}{l}\text { Cps-2 Nutrition } \\
\text { cohort study }\end{array}$ & $\begin{array}{l}\text { Mailed } \\
\text { questionnaire }\end{array}$ & NR \\
\hline
\end{tabular}

Table 2. Analysis of Taking Aspirin and NHL Risk

\begin{tabular}{|c|c|c|c|c|c|c|}
\hline \multirow[t]{2}{*}{ variable } & \multirow[t]{2}{*}{ No. of studies } & \multicolumn{2}{|c|}{ Odds ratio } & \multirow[t]{2}{*}{ Model } & \multicolumn{2}{|c|}{ Heterogeneity } \\
\hline & & $\overline{95 \% \mathrm{CI}}$ & $\overline{\mathrm{P}}$ & & $\overline{\mathrm{I}^{2}(\%)}$ & $\overline{\mathrm{P}}$ \\
\hline Aspirin & 7 & $1.09(0.87-1.16)$ & 0.9 & Random & 59 & 0.004 \\
\hline
\end{tabular}


Table 3. Analysis of Taking Aspirin and Subgroup NHL Risk

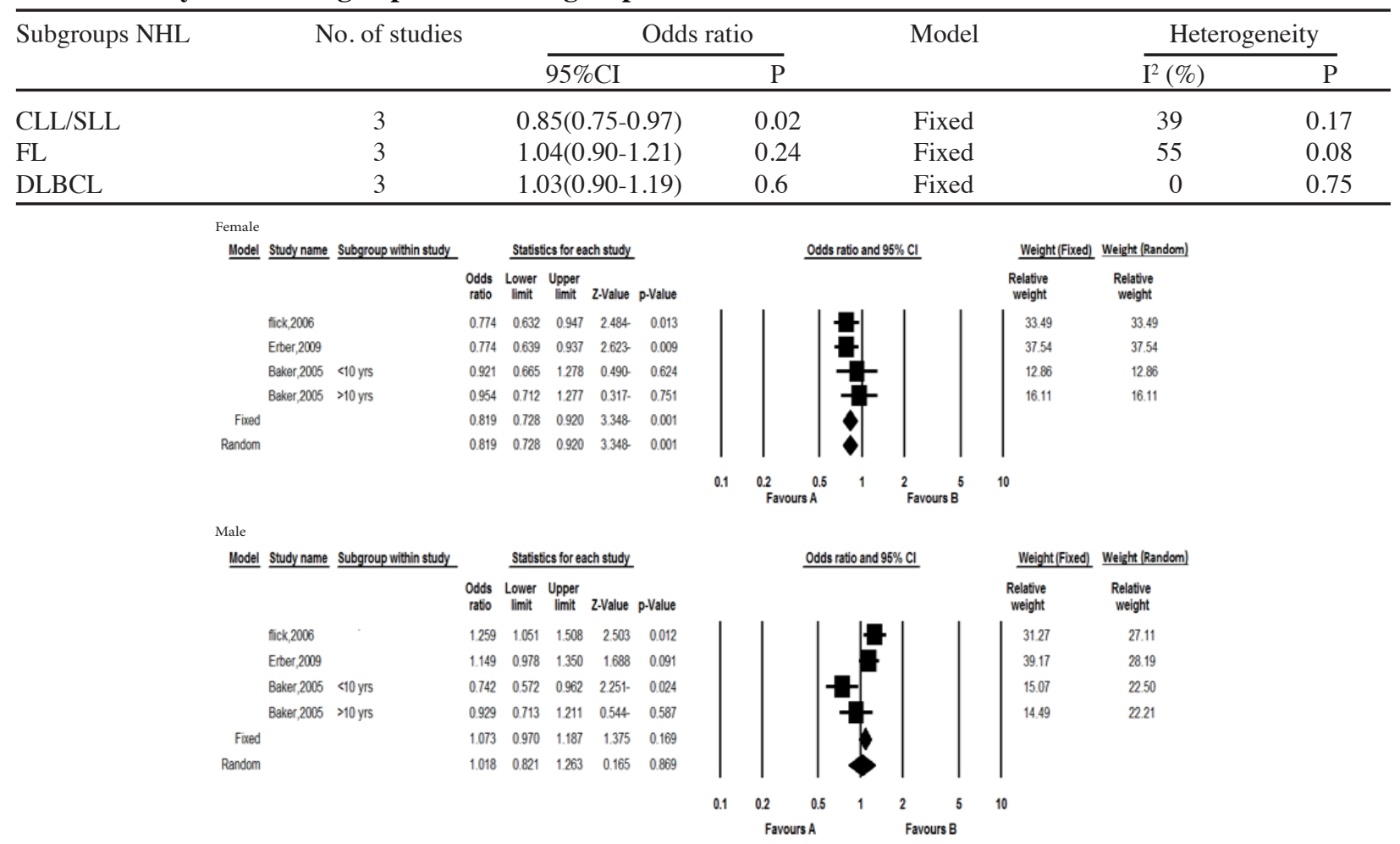

Figure 4. Risk Estimates of the Odds Ratio of Developing NHL for Persons who Received Aspirin, by Sex DLBCL
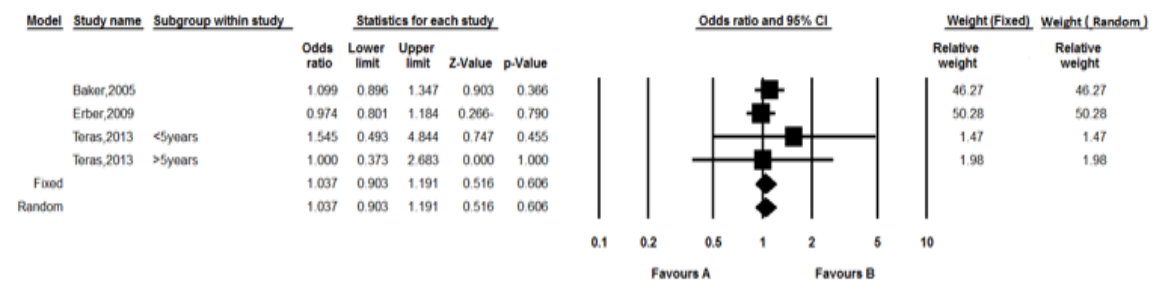

CLL/SLL

\begin{tabular}{|c|c|c|c|c|c|c|c|}
\hline \multirow{2}{*}{ Model } & \multirow[t]{2}{*}{ Study name } & \multirow[t]{2}{*}{ Subgroup within study } & \multicolumn{5}{|c|}{ Statistics for each study } \\
\hline & & & $\begin{array}{l}\text { Odds } \\
\text { ratio }\end{array}$ & $\begin{array}{c}\text { Lower } \\
\text { limit }\end{array}$ & $\begin{array}{l}\text { Upper } \\
\text { limit }\end{array}$ & Z.Value & p.Value \\
\hline & Baker,2005 & & 0.821 & 0.671 & 1.004 & 1.925 & 0.054 \\
\hline & Erber,2009 & & 0.762 & 0.610 & 0.953 & 2.384 & 0.017 \\
\hline & Teras, 2013 & syears & 1.136 & 0.841 & 1.536 & 0.830 & 0.406 \\
\hline & Teras,2013 & >5years & 1.108 & 0.458 & 2.681 & 0.228 & 0.820 \\
\hline Fived & & & 0.857 & 0.751 & 0.979 & 2.281 . & 0.023 \\
\hline andom & & & 0.877 & 0.728 & 1.056 & 1.363. & 0.167 \\
\hline
\end{tabular}
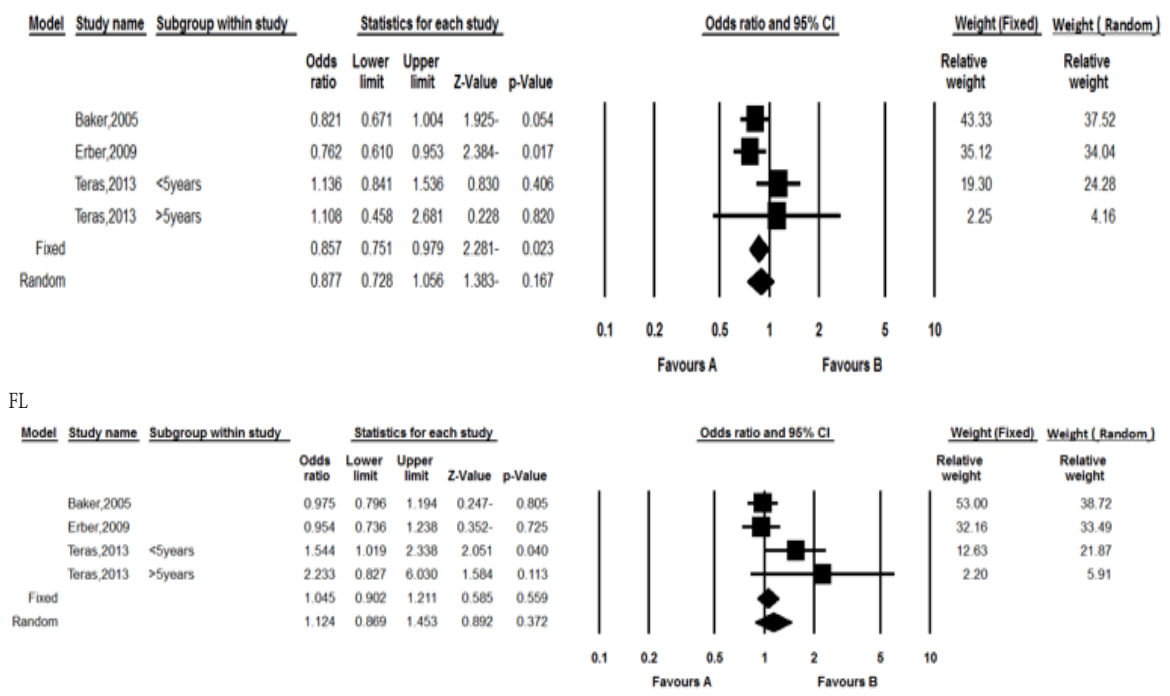

Figure 5. Risk Estimates of the Odds Ratio of Developing NHL for Persons who Received Aspirin, by Lymphoma Subtype. FL indicates follicular lymphoma. DLBCL, Diffuse large B-cell lymphoma and CLL/SLL, chronic lymphocytic leukemia/ small lymphocytic lymphoma

revealed no statistical significant association between:(a) Diffuse large B-cell lymphoma (DLBCL) (OR=1.03, 95\%CI:0.9-1.19, p=0.6); (b) Follicular lymphoma (FL) $(\mathrm{OR}=1.12,95 \% \mathrm{CI}: 0.86-1.45, \mathrm{p}=0.37)$ and showed no statistical significant association between lymphocytic leukemia/small lymphocytic lymphoma (CLL/SLL) $(\mathrm{OR}=0.85$, (95\%CI: 0.86-1.45, $\mathrm{p}=0.37)$ (Figure 5). The results are shown in Tables 2 and Table 3 .

\section{Discussion}


In this study, there was evidence indicated that there was not a significant association between exposure to aspirin and developed NHL. Also, according to analysis of subgroups, a statistically significant difference was observed in the effect of taking aspirin in women suffered from NHL. There was a relation between gender, exposure to aspirin, and NHL. There was a strong statistical association was seen between taking aspirin and the risk of chronic lymphocytic leukemia in different subtypes.

Cerhan et al evaluated the association between taking aspirin and other Non-steroidal drugs, and risk of NHL in post menopausal women with a history of rheumatoid arthritis (RA). The NHL risk (RR) was 1.1.71 in those who were only taking aspirin (95\%CI: 0.94-3.13) while RR was 2.39 in those who were taking NSAIDs (95\%CI: 1.18-4.83). The result showed that the use of NSAIDs, including aspirin, has been associated with increasing the risk of NHL. However, this association was independent of RA history, and effects of NSAIDs and aspirin were same in RA and non RA Populations(Cerhan et al., 2003). In contrast, Smedby et al determined that the increased risk of NHL was seen in patients with RA (OR: 1.5, 95\%CI : 1.1-1.9) so that individuals who are not suffering from RA are not suffering from NHL (Chang et al., 2005). This can likely be due to the effects of modification or confounding factors.New evidence has shown; the importance of NHL severity in autoimmune diseases such as RA. The nested case control study has developed the strongest evidence for this association, and RR of developing NHL in patients with AR was 71 (95\%CI: 24-211) (Baecklund et al., 2006). Other studies suggest that after adjusting severity of NHL the possible association seem less between RA medication and the lymphoma risk. Setoguchi et al reported that after adjusting severity of NHL the relative risk of developing the types of leukemia (haematological) is almost the same in the recipients of the drugs as the anti-tumournecrosis factor (TNF) or Methotrexate (Setoguchi et al., 2006). A study indicated that in persons who taking NSAIDs or NNAS (Non-nacrotic analagesis) over 10 years compared to those who not taking such drugs, the risk of NHL is almost twice (OR: 1.9, 95\%CI: 1.01-3.57). Also, various drugs were evaluated based on their length. Many evidences showed a relation between the length of taking drugs (over 10 years) and Ibuprofen. However, there was no significant relation between duration of taking aspirin and the risk of NHL (Kato et al., 2002). In contrast, another study indicated that in individuals who not taking NSAIDs, the adjusted OR has decreased among men and women, but estimating the adjusted OR was null among aspirin users except women. Also, in female who taking aspirin between 3 and less than 9 years reducing the risk of NHL was reported nearly $59 \%$ (Flick et al., 2006). A study determined that a significant association was not observed between the use of NSAIDs and NHL while the risk of follicular lymphoma (of NHL subgroups) has been increased (HR: 1.87, 95\%CI: 1.08-3.24) (Teras et al., 2013).

Data from surveillance, epidemiology, and End results program has shown that the age standardized incidence rates of NHL has increased 3 to $4 \%$ annually from 1970 to 1980 s (Ekstrom et al., 2006). Since 1991 the annual increase in the incidence was $0.4 \%$ and $1.2 \%$ respectively in men and women (Siegel et al., 2011).

Limitation In this meta-analysis, there were a number of limitations and potential bias. First, it seemed that 4 studies had the inclusion criteria, but it was not possible to access the full-texts of them. This may increase the likelihood of selection bias. Second, we intend to evaluate the effects of other confounding variables such as autoimmune diseases, which increase the likelihood of information bias. Despite these limitations, this metaanalysis can provide strong evidence of a significant association between aspirin and NHL. Since senility analyses, limiting the inclusion of studies according to the data of publication or the size of the study, produce results nearly identical to the primary result.

In addition, new information was obtained about the relation between exposure to aspirin and the NHL, as follows:

i) Obtaining a summary of data on estimating odds ratio, risk ratio, and the hazard ratio according to the effect of aspirin on NHL. NHL.

ii) No statistically significant effect of aspirin on the

iii) Significant direct correlation between the effects of aspirin and incidence Diffuse large B-cell lymphoma (DLBCL).

$i v)$ Identifying the impact of different variables on the relation between aspirin use and NHL, such as: studies design, quality of studies, and duration of treatment.

In conclusion, in this study, finding has shown in those patients who had taken aspirin was not appearing to independently increase risk of Non-Hodgkins lymphoma.

\section{References}

Amanat A, Al-Belushi B, I Waly M, Al-Moundhri M, A Burney Ik (2013). Dietary and lifestyle factors and risk of nonHodgkin's lymphoma in Oman. Asian Pac J Cancer Prev, 14, 841-8.

848.

Amoori N, Mirzaei M, Cheraghi M(2014). Incidence of cancers in Kuzestan province of Iran: trend from 2004 to 2008. Asian Pac J Cancer Prev, 15, 8345-9.

Ansell SM, Armitage J (2005). Non-Hodgkin lymphoma: diagnosis and treatment. Proc Mayo Clinic, 80, 1087-97.

Baker JA, Weiss JR, Czuczman MS, et al (2005). Regular use of aspirin or acetaminophen and risk of non-Hodgkin lymphoma. Cancer Causes Control, 16, 301-8.

Baecklund E, Iliadou A, Askling J, et al (2006). Association of chronic inflammation, not its treatment, with increased lymphoma risk in rheumatoid arthritis. Arthritis Rheum, 54, 692-701.

Binesh F, Akhavan A, Behniafard N, Atefi A (2014). Clinicopathologic and survival characteristics of childhood and adolescent non Hodgkin's lymphoma in Yazd, Iran. Asian Pac J Cancer Prev, 15, 1585-8.

Boffetta P, de Vocht F (2007). Occupation and the risk of nonHodgkin lymphoma. Cancer Epidemiol Biomarkers Prev, 16, 369-72.

Broccia G, Cocco P, Casula P (2001). Incidence of nonHodgkin's lymphoma and Hodgkin's disease in Sardinia, Italy: 1974-1993. Haematologica, 86, 58-63.

Cerhan JR, Anderson KE, Janney CA, et al (2003). Association 


\section{Maria Cheraghi et al}

of aspirin and other non-steroidal anti-inflammatory drug use with incidence of non-Hodgkin lymphoma. Int J Cancer, 106, 784-8.

Chang ET, Smedby KE, Hjalgrim H, et al (2005). Medication use and risk of non-Hodgkin's lymphoma. Am J Epidemiol, 162, 965-74.

Chia SE, Wong KY, Tai BC (2012). Occupation and risk of nonHodgkin's lymphoma in Singapore. Occup Med, 62, 29-33.

Clarke CA, Glaser SL(2002). Changing incidence of nonhodgkin lymphomas in the United States. Cancer. 94, 2015-23.

Devesa SS, Fears T (1992). Non-Hodgkin's lymphoma time trends: United States and international data. Cancer research, 52, 5432-40.

Erber E, Lim U, Maskarinec G, Kolonel LN(2009). Common immune-related risk factors and incident non-Hodgkin lymphoma: The multiethnic cohort. Int J Cancer, 125, 1440-5.

Ekstrom-Smedby K (2006). Epidemiology and etiology of non-Hodgkin lymphoma--a review. Acta Oncol, 45, 258-71.

Flick ED, Chan KA, Bracci PM, Holly EA (2006). Use of nonsteroidal antiinflammatory drugs and non-Hodgkin lymphoma: a population-based case-control study. Am J Epidemiol, 497, 164-504.

Goldin LR, Bjorkholm M, Kristinsson SY, Turesson I, Landgren $\mathrm{O}$ (2009). Elevated risk of chronic lymphocytic leukemia and other indolent non-Hodgkin's lymphomas among relatives of patients with chronic lymphocytic leukemia. Haematologica, 94, 647-53.

Hernandez BY, Green MD, Cassel KD, et al (2010). Cancer Research Center Hotline: Preview of Hawai 'i Cancer Facts and Figures 2010. Hawaii Med J, 69, 223.

Higgins JPT, Thompson SG, Deeks JJ, Altman DG (2003). Measuring inconsistency in meta-analyses. BMJ, 327, 557-60.

Hoshida Y, Xu J-X, Fujita S, et al (2007). Lymphoproliferative disorders in rheumatoid arthritis: clinicopathological analysis of 76 cases in relation to methotrexate medicatio. $J$ Rheumatol, 34, 322-31.n

Karami K, Cheraghi M, Amori N, Pedram M, Sobhani A(2014). Common cancers in Khuzestan province, South West of Iran, during 2005-2011. Asian Pac J Cancer Prev, 15, 9475-8.

Kato I, Koenig KL, Shore RE, et al (2002). Use of antiinflammatory and non-narcotic analgesic drugs and risk of non-Hodgkin's lymphoma (NHL)(United States). Cancer Causes Control, 13, 965-74.

Rothwell PM, Fowkes FGR, Belch JF, et al (2011). Effect of daily aspirin on long-term risk of death due to cancer: analysis of individual patient data from randomised trials. Lancet, 377, 31-41.

Rothwell PM, Price JF, Fowkes FGR, Zanchetti A, Roncaglioni MC, Tognoni G, et al (2012). Short-term effects of daily aspirin on cancer incidence, mortality, and non-vascular death: analysis of the time course of risks and benefits in 51 randomised controlled trials. Lancet, 379, 1602-12.

Sangrajrang S, Renard H, Kuhaprema T, et al (2011). Personal use of hair dyes--increased risk of non-Hodgkin's lymphoma in Thailand. Asian Pac J Cancer Prev, 12, 2393-6.

Setoguchi S, Solomon DH, Weinblatt ME, et al (2006). Tumor necrosis factor $\alpha$ antagonist use and cancer in patients with rheumatoid arthritis. Arthritis Rheum, 54, 2757-64.

Siegel R, Ward E, Brawley O, Jemal A (2011). Cancer statistics. CA Cancer J Clin, 61, 212-36.

Teras LR, Gapstur SM, Patel AV, et al (2013). Aspirin and other nonsteroidal anti-inflammatory drugs and risk of non-hodgkin lymphoma. Cancer Epidemiol Biomarkers Prev, 22, 422-8.
Thun MJ, Jacobs EJ, Patrono C (2012). The role of aspirin in cancer prevention. Nat Rev Clin Oncol, 9, 259-67.

Zhang Y, Coogan PF, Palmer JR, Strom BL, Rosenberg L (2006). Risk of non-Hodgkin lymphoma and use of non-steroidal anti-inflammatory drugs. Cancer Detect Prev, 30, 99-101.

Zekri AR, Hassan ZK, Bahnassy AA et al (2013). Gene expression profiling of non-Hodgkin lymphomas. Asian Pac J Cancer Prev, 14, 4393-8.

Zelenetz AD, Abramson JS, Advani RH, et al (2010). NonHodgkin's lymphomas. J Nat Compr Cancer Netw, 8 , 288-334.

Yildirim M, Karakilinc H, Yildiz M, et al (2013). Non-Hodgkin lymphoma and pesticide exposure in Turkey. Asian Pacific J Cancer Prev, 14, 3461-3. 